\title{
Pembuatan dan Karakterisasi Dissolving Pulp Serat Panjang dari Bambu Duri (Bambusa blumeana)
}

\author{
Chandra Apriana Purwita*, Susi Sugesty \\ Balai Besar Pulp dan Kertas Jl. Raya Dayeuhkolot No 132, Bandung, Indonesia
}

Diterima : 14 November 2017, Revisi akhir : 03 Mei 2018, Disetujui terbit : 07 Mei 2018

\section{Preparation and Characterization of Long Fiber Dissolving Pulp from Spiny Bamboo (Bambusa blumeana)}

\begin{abstract}
The need for long fiber dissolving pulp in Indonesia can only be met from imports. Bamboo is a nonwood plant and known as source of long fiber. This research aims to study the potential of spiny bamboo to be used as raw material for producing long fiber dissolving pulp. This research was conducted using two different types of raw materials preparation to produce bamboo chip and decorticated bamboo. The pulping process is carried out by pre-hydrolysis kraft and bleaching performed with two different bleaching sequences, i.e $D_{0} E D_{1} D_{2}$ and $D_{o} E p D_{1} D_{2}$. Based on the experimental results, spiny bamboo has good potential to be used as raw material for dissolving pulp. Spiny bamboo belongs to long fibers with an average fiber length of $2.46 \mathrm{~mm}$. The dissolving quality depends on the preparation of the raw material and the bleaching sequence. The yield of spiny bamboo dissolving pulp ranged from 37.97 $40.76 \%$ with alpha cellulose content of $94.88-98.67 \%$, and viscosity of $16.43-25.75$ cP. Decorticated bamboo with bleaching sequence of $D_{0} E p D_{1} D_{2}$ produced the highest quality of dissolving pulp with the highest brightness and alpha cellulose were $89.61 \%$ ISO and $98.67 \%$, respectively.
\end{abstract}

Keywords: dissolving pulp, spiny bamboo (Bambusa blumeana), bamboo chip, decorticated bamboo, pre-hydrolysis kraft

\begin{abstract}
Abstrak
Kebutuhan dissolving pulp serat panjang di Indonesia hanya dapat dipenuhi melalui impor. Bambu adalah tanaman nonkayu dan dikenal sebagai sumber serat panjang. Penelitian ini bertujuan untuk mempelajari potensi bambu duri untuk dijadikan bahan baku pembuatan dissolving pulp serat panjang. Penelitian ini dilakukan dengan dua jenis persiapan bahan baku yang berbeda untuk menghasilkan serpih bambu dan bambu dekortikasi. Proses pemasakan dilakukan dengan proses pra-hidrolisis kraft dan pemutihan dilakukan dengan dua urutan pemutihan yang berbeda, yaitu $\mathrm{D}_{0} \mathrm{ED}_{1} \mathrm{D}_{2}$ dan $\mathrm{D}_{0} \mathrm{EpD}_{1} \mathrm{D}_{2}$. Berdasarkan hasil penelitian, bambu duri memiliki potensi yang baik untuk digunakan sebagai bahan baku pembuatan dissolving pulp. Bambu duri tergolong serat panjang dengan panjang serat rata-rata 2,46 mm. Kualitas dissolving pup yang dihasilkan tergantung dari persiapan bahan baku dan urutan pemutihan. Rendemen dissolving pulp bambu duri berkisar 37,97 - 40,76\%, dengan kandungan selulosa alfa 94,88 - 98,67\%, dan viskositas 16,43 - 25,75 cP. Bambu dekortikasi dengan urutan pemutihan $\mathrm{D}_{0} \mathrm{EpD}_{1} \mathrm{D}_{2}$ menghasilkan dissolving pulp paling unggul dengan derajat cerah dan selulosa alfa tertinggi berturut-turut $89,61 \%$ ISO dan $98,67 \%$.
\end{abstract}

Kata kunci: dissolving pulp, bambu duri (Bambusa blumeana), serpih bambu, bambu dekortikasi, prahidrolisis kraft 


\section{Pendahuluan}

Permintaan pasar global dan kebutuhan dissolving pulp meningkat dari tahun ke tahun. Di Indonesia, kebutuhan dissolving pulp serat panjang sebesar 400.000 ton hingga 500.000 ton per tahun dan diproyeksikan terus meningkat (Ariyanti, 2018). Peningkatan ini diperkirakan akan terus tumbuh dan didorong oleh pertumbuhan industri serat rayon. Bahan utama pembuatan serat rayon adalah pulp khusus yang disebut dissolving pulp. Dissolving pulp adalah pulp putih rendemen rendah yang memiliki kandungan selulosa alfa serta derajat cerah yang tinggi sementara kandungan ekstraktif, hemiselulosa, dan abu rendah. Dissolving pulp diproduksi dengan dua metode yaitu prahidrolisis kraft dan sulfit asam. Pra-hidrolisis kraft menghasilkan dissolving pulp dengan kadar selulosa alfa sampai $94 \%-96 \%$ dan sulfit asam menghasilkan kadar selulosa alfa yang lebih rendah yaitu sebesar 90\%-92\%. Dissolving pulp digunakan untuk pembuatan serat rayon dan berbagai turunan selulosa. Serat rayon adalah serat serbaguna yang digunakan untuk menggantikan kapas pada pembuatan pakaian. Sebagian besar serat rayon dibuat dengan proses viskosa. Pada pembuatan serat rayon viskosa, dissolving pulp serat panjang dibutuhkan untuk membentuk kekuatan serat yang baik. Oleh karena itu, pada pembuatan serat rayon viskosa, industri selalu mencampur dissolving pulp serat pendek dan panjang. Meskipun permintaan dissolving pulp serat panjang di Indonesia cukup tinggi, namun tidak dapat dipenuhi karena Indonesia tidak memproduksi dissolving pulp serat panjang sehingga harus dipenuhi melalui impor (Ariyanti, 2018).

Indonesia adalah negara tropis yang kaya akan tanaman nonkayu yang dapat digunakan sebagai bahan baku alternatif untuk industri pulp dan kertas. Salah satu jenis tanaman nonkayu tersebut adalah bambu. Bambu adalah istilah umum untuk anggota rumput kayu, subfamily Bambusoideae dan family Andropogoneae/Poacea. Bambu memiliki beberapa keunggulan dibandingkan dengan tanaman kayu yaitu tumbuh cepat dan bisa dipanen setelah 3-5 tahun tanam, jauh lebih pendek dari kayujarum yang butuh waktu 10-20 tahun. Selain itu, bambu memiliki produktivitas tinggi dan dapat tumbuh di tanah gersang (Truong and Le, 2014). Sebagai tanaman nonkayu, bambu dikenal karena seratnya panjang dengan panjang serat rata-rata 1,90-3,24 (Tian et al., 2013; Cao et al., 2014; Maya and Narasimhamurthy, 2015;
Sugesty, Kardiansyah and Hardiani, 2015) sehingga berpotensi besar digunakan sebagai bahan baku alternatif untuk memproduksi dissolving pulp serat panjang untuk mengurangi ketergantungan pada impor.

Jumlah spesies bambu yang ada di dunia sekitar 1030 jenis yang berasal dari 77 genus. Sekitar 200 spesies dari 20 genus ditemukan di Asia Tenggara dan sebanyak 143 spesies bambu tumbuh di Indonesia. Bambu tersebar di pulau Jawa sebanyak 60 spesies. Sembilan spesies merupakan spesies endemik di pulau Jawa (Dransfield and Widjaja, 1995). Beberapa spesies bambu telah diteliti sebagai bahan baku pembuatan dissolving pulp antara lain apus (Gigantochloa apus), sembilang (Dendrocalamus giganteus), petung (Dendrocalamus asper), mayan (Gigantochloa robusta) (Sugesty, Kardiansyah and Hardiani, 2015), bambu hijau (Dendrocalamopsis oldhami) (Ma et al., 2011; Cao et al., 2014; Luo et al., 2014), dan bambu komersil (Batalha et al., 2012). Penelitian terus dilakukan untuk menyelidiki spesies bambu yang potensial untuk digunakan sebagai bahan baku pembuatan dissolving pulp serat panjang dengan kualitas yang baik. Penelitian ini menggunakan spesies bambu yang merupakan spesies endemik yaitu bambu duri (Bambusa blumeana) yang diyakini berasal dari Sumatera, Jawa, dan Kalimantan. Bambu duri merupakan salah satu jenis bambu yang banyak dibudidayakan di Indonesia dan dimanfaatkan untuk konstruksi, furnitur, peralatan dapur, dan kerajinan lainnya. Spesies bambu ini belum pernah diteliti sebagai bahan baku pada pembuatan dissolving pulp sehingga penting untuk dilakukan penelitian untuk menggali potensi bambu duri.

Produksi dissolving pulp berkualitas baik melibatkan dua aspek penting yaitu kualitas bahan baku dan proses pembuatan dissolving pulp. Kualitas bahan baku dapat diperiksa melalui analisis dimensi serat seperti panjang dan diameter serat, dan analisis komponen kimia misalnya kandungan selulosa alfa (Biermann, 1996). Proses pembuatan dissolving pulp meliputi persiapan bahan baku, pra-hidrolisis, pemasakan, dan pemutihan juga menentukan kualitas dissolving pulp. Perbedaan persiapan bahan baku menghasilkan dimensi bahan baku, kadar air, kandungan komponen kimia seperti selulosa, lignin, abu dan ekstraktif yang berbeda sehingga mempengaruhi kualitas dissolving pulp. Oleh karena itu, penelitian dilakukan untuk mengetahui 
pengaruh persiapan bahan baku terhadap kualitas dissolving pulp yang dihasilkan. Standar Nasional Indonesia 938:2017-Pulp rayon mempersyaratkan derajat cerah dissolving pulp minimal $89 \%$ ISO. Derajat cerah yang tinggi hanya dapat diperoleh dengan mengoptimalkan proses pemasakan dan pemutihan. Kondisi pemasakan seperti rasio bahan baku terhadap cairan kimia pemasak, persentase alkali aktif, sulfiditas, temperatur dan waktu pemasakan menentukan kualitas pulp belum putih yang dihasilkan yang kemudian dapat mempengaruhi kualitas dissolving pulp yang dihasilkan. Kualitas dissolving pulp terutama derajat cerah dipengaruhi oleh urutan tahapan pemutihan yang digunakan sehingga penting untuk menentukan tahapan pemutihan sehingga memperoleh derajat cerah dissolving pulp yang memenuhi persyaratan SNI 938:2017 - Pulp rayon. Penelitian ini bertujuan untuk mengetahui potensi bambu duri untuk dijadikan bahan baku pembuatan dissolving pulp serat panjang. Secara khusus untuk mengetahui pengaruh persiapan bahan baku dan urutan tahap pemutihan terhadap kualitas dissolving pulp yang dihasilkan.

\section{Bahan dan Metode}

\section{Persiapan Bahan Baku}

Bambu duri (Bambusa blumeana) berumur empat tahun diperoleh dari Hutan Percobaan Arcamanik, Pusat Penelitian dan Pengembangan Rehabilitasi dan Konservasi Hutan. Bambu dipanen lalu dikeringkan di bawah sinar matahari. Bagian bambu yang digunakan dalam percobaan adalah ruasnya. Buku bambu dipotong dan disisihkan karena kandungan mineral yang tinggi namun kandungan serat rendah. Percobaan ini menggunakan dua jenis persiapan bahan baku yang berbeda untuk menghasilkan serpih bambu dan bambu dekortikasi. Serpih bambu disiapkan dengan cara memotong ruas sebesar $3 \mathrm{~cm} \times$ $2,5 \mathrm{~cm} \times 1 \mathrm{~cm}$. Bambu dekortikasi disiapkan dengan memotong ruas memanjang dengan ketebalan $2 \mathrm{~cm}$. Bambu direndam dalam air selama 24 jam lalu dipipihkan dengan alat press. Bambu kemudian dikeringkan di bawah sinar matahari. Bambu kering kemudian didekortikasi dengan menggunakan dekortikator laboratorium kemudian diayak dengan wood chip screener. Bambu dekortikasi yang digunakan pada penelitian adalah bambu dengan panjang $3 \mathrm{~cm}-5$ $\mathrm{cm}$ dan ketebalan $0,2 \mathrm{~cm}-1 \mathrm{~cm}$.

\section{Analisis Dimensi Serat dan Turunannya}

Dimensi serat seperti panjang serat, diameter serat, diameter lumen, ketebalan dinding dianalisis sesuai SNI 01-1840-1990 - Cara uji panjang serat kayu dan bukan kayu. Parameter turunan dimensi serat dihitung berdasarkan data primer dimensi serat.

\section{Analisis Komponen Kimia}

Persiapan contoh untuk analisis komponen kimia dilakukan dengan cara memotong bambu $5 \mathrm{~cm} \times 0,5 \mathrm{~cm} \times 0,5 \mathrm{~cm}$ dan kemudian dibuat menjadi serbuk dengan Wiley mill. Serbuk bambu kemudian diayak dengan saringan mesh. Ukuran partikel bambu yang digunakan untuk analisis adalah lolos 40 mesh dan tertahan 60 mesh. Parameter analisis bambu adalah: selulosa alfa (SNI 0444: 2009 Pulp - Cara uji kadar selulosa alfa, beta dan gamma), holoselulosa (ASTM D1104-56-Method of test for holocellulose in wood), ekstraktif alkohol benzena (SNI 8401:2017-Ekstraktif terlarut pada kayu dan pulp (T $204 \mathrm{~cm}-07$, IDT)), lignin tak larut asam (SNI 8429: 2017-Lignin tidak larut asam dalam kayu dan pulp (T 222 om-15, IDT)), pentosan (SNI 141304-1989-Cara uji kadar pentosan pulp kayu), abu (SNI 0442: 2009-Kertas, karton dan pulpCara uji kadar abu pada 525 derajat Celsius), abu tak larut asam (SNI ISO 776: 2010 Pulp-Cara uji kadar abu tidak larut asam), kelarutan dalam air dingin dan panas (SNI 01-1305-1989 Kayu-Cara uji kelarutan dalam air dingin dan air panas), dan kelarutan $\mathrm{NaOH}$ 1\% (SNI 14-1838-1990-Cara uji kelarutan kayu dan pulp dalam larutan natrium hidroksida satu persen).

\section{Pemasakan Pra-Hidrolisis Kraft}

Pemasakan pra-hidrolisis kraft dilakukan baik terhadap serpih bambu maupun bambu dekortikasi. Bambu sebanyak 350 gram kering oven kemudian dimasukkan ke dalam bejana digester, lalu ditambahkan asam sulfat $1 \mathrm{~N}$ dengan perbandingan padatan dan cair adalah 1: $5(\mathrm{w} / \mathrm{v})$. Bambu dimasak dengan suhu $160^{\circ} \mathrm{C}$ selama 145 menit (waktu untuk mencapai suhu maksimum adalah 55 menit dan ditahan selama 90 menit). Pulp kemudian dipisahkan dari prehydrolysis liquor lalu dicuci dengan air hingga netral.

Bambu hasil dari pra-hidrolisis asam kemudian ditentukan kadar airnya. Pulp kemudian 
dimasukkan dalam reaktor $\mathrm{CRS} \mathrm{AB}$ rotary digester dengan kapasitas 6 L. Bambu dimasak pada suhu $160^{\circ} \mathrm{C}$ selama 90 menit untuk mencapai suhu maksimum dan ditahan selama 120 menit sehingga total waktu adalah 210 menit, faktor $\mathrm{H}$ adalah 800 . Jumlah alkali aktif adalah $16 \%$ dan sulfiditas adalah $30 \%$. Pulp kemudian dipisahkan dari lindi hitam lalu dicuci dan di-screening untuk memisahkan dengan reject. Bagian yang tidak lolos saringan dinyatakan sebagai reject. Rendemen pulp dihitung berdasarkan berat kering oven pulp yang lolos saringan dibagi berat kering oven bahan baku.

\section{Pemutihan}

Pemutihan dilakukan dengan dua urutan berbeda yaitu $\mathrm{D}_{0} E D_{1} \mathrm{D}_{2}$ dan $\mathrm{D}_{0} \operatorname{EpD}_{1} \mathrm{D}_{2}\left(\mathrm{D}_{\mathrm{o}}=\right.$ ekstraksi awal klorin dioksida, E: ekstraksi alkali, Ep: ekstraksi alkali peroksida, $\mathrm{D}_{1}$ dan $\mathrm{D}_{2}$ : klor dioksida tahap pertama dan kedua) untuk mempelajari pengaruh urutan pemutihan pada kualitas dissolving pulp. Kondisi lengkap setiap tahap pemutihan disajikan pada Tabel 1 dan Tabel 2. Dosis $\mathrm{ClO}_{2}$ pada $\mathrm{D}_{0}$ dihitung berdasarkan Faktor Kappa Number yaitu 22\% terhadap bilangan Kappa pulp belum putih.

\section{Analisis Dissolving Pulp}

Dissolving pulp dianalisis sesuai dengan Standar Nasional Indonesia. Parameternya adalah selulosa alfa (SNI 0444: 2009 Pulp - Cara uji kadar selulosa alfa, beta dan gamma), $\mathrm{S}_{10}$ dan $\mathrm{S}_{18}$ (SNI 692: 2010 Pulp-Cara uji kelarutan dalam alkali), ekstraktif dikloro metana (DCM) (SNI 8401:2017 Ekstraktif terlarut pada kayu dan pulp (T 204 cm-07, IDT)), abu (SNI 0442: 2009

Tabel 1. Kondisi Pemutihan untuk Urutan Pemutihan $\mathrm{D}_{\mathrm{o}} \mathrm{ED}_{1} \mathrm{D}_{2}$

\begin{tabular}{lcccc}
\hline Kondisi & $\mathrm{D}_{\mathrm{o}}$ & $\mathrm{E}$ & $\mathrm{D}_{1}$ & $\mathrm{D}_{2}$ \\
\hline Konsistensi, \% & 10 & 10 & 10 & 10 \\
$\mathrm{NaOH}, \%$ & - & 1 & - & - \\
Faktor KN, \% & 22 & - & - & - \\
$\mathrm{ClO}_{2}, \%$ & - & - & 1 & 0,5 \\
Waktu, mnt $^{\circ}$ & 60 & 60 & 180 & 180 \\
Temperatur, ${ }^{\circ} \mathrm{C}$ & 60 & 70 & 75 & 75 \\
pH akhir & $2,5-3,5$ & $11,5-12$ & 4 & 3,5 \\
\hline
\end{tabular}

Kertas, karton dan pulp-Cara uji kadar abu pada 525 derajat Celsius), viskositas dalam larutan kuprietilendiamina (CED) (SNI 0936: 2008 Pulp - Cara uji viskositas - Kuprietilendiamin (viskometer kapiler)); viskositas intrinsik (SNI 5351: 2012 Pulp - Cara uji bilangan viskositas limit (viskositas intrinsik) dalam larutan kuprietilendiamina (CED)); dan derajat cerah (SNI 2470-1: 2014 Kertas, karton, dan pulp Cara uji faktor pantul biru cahaya baur - Bagian 1: Kondisi siang hari di dalam ruangan (derajat cerah ISO).

\section{Hasil dan Pembahasan}

\section{Hasil Persiapan Bahan Baku}

Kualitas dissolving pulp yang dihasilkan selain dipengaruhi oleh jenis bahan baku, proses pemasakan, dan pemutihan, juga dipengaruhi oleh persiapan bahan baku. Bambu dipersiapkan dengan dua metode yang berbeda untuk menghasilkan serpih bambu dan bambu dekortikasi untuk mempelajari pengaruh persiapan bahan baku terhadap kualitas dissolving pulp yang dihasilkan (Gambar 1).

Dekortikasi merupakan proses untuk memisahkan serat dengan perlakuan mekanik. Pemisahan serat dari bagian nonserat diharapkan meningkatkan kandungan selulosa alfa bahan dan menurunkan kandungan abu sehingga meningkatkan mutu pulp yang dihasilkan. Perbedaan dalam persiapan bahan baku menghasilkan dimensi bahan yang berbeda.

Tabel 2. Kondisi Pemutihan untuk Urutan Pemutihan $\mathrm{D}_{\mathrm{o}} \mathrm{EpD}_{1} \mathrm{D}_{2}$

\begin{tabular}{lcccc}
\hline Kondisi & $\mathrm{D}_{\mathrm{o}}$ & $\mathrm{Ep}$ & $\mathrm{D}_{1}$ & $\mathrm{D}_{2}$ \\
\hline Konsistensi, \% & 10 & 10 & 10 & 10 \\
$\mathrm{NaOH}, \%$ & - & 1 & - & - \\
Faktor KN, \% & 22 & - & - & - \\
$\mathrm{ClO}_{2}, \%$ & - & - & 1 & 0,5 \\
$\mathrm{H}_{2} \mathrm{O}_{2}, \%$ & 0 & 2 & 0 & 0 \\
$\mathrm{EDTA}^{\circ} \%$ & - & 0.5 & - & - \\
$\mathrm{Na}_{2} \mathrm{SiO}, \%$ & - & 5 & - & - \\
$\mathrm{Waktu}_{3}$, menit & 60 & 60 & 180 & 180 \\
$\mathrm{Temperatur}^{\circ} \mathrm{C}$ & 60 & 70 & 75 & 75 \\
pH akhir & $2,5-3,5$ & $11,5-12$ & 4 & 3,5 \\
\hline
\end{tabular}



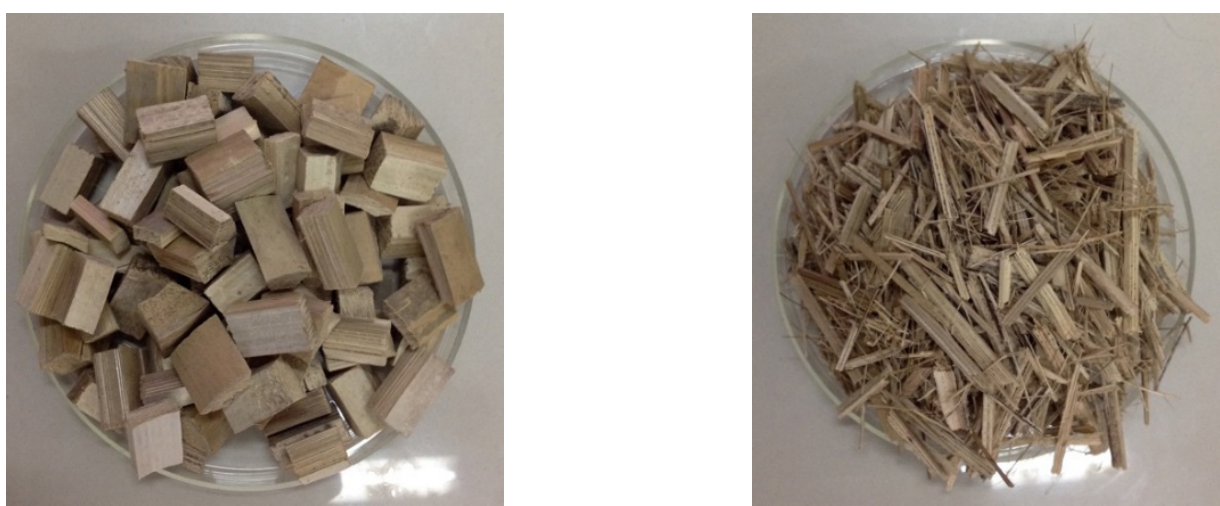

Gambar 1. Serpih Bambu (Kiri) dan Bambu Dekortikasi (Kanan)

Perbedaan ini menentukan kualitas bahan baku yang dapat mempengaruhi kualitas dissolving pulp yang dihasilkan.

\section{Dimensi Serat dan Turunannya}

Dimensi serat seperti panjang serat, diameter serat dan lumen, ketebalan dinding, serta nilai turunannya digunakan untuk mengetahui kualitas bahan baku dan pulp yang dihasilkan (Cao et al., 2014; Duan et al., 2015). Panjang serat adalah salah satu besaran serat yang paling penting. Dibandingkan dengan serpih bambu, bambu dekortikasi memiliki panjang serat rata-rata lebih besar dan diameter serat yang lebih kecil. Naiknya panjang serat rata-rata pada bambu dekortikasi dapat disebabkan karena aksi mekanik proses dekortikasi menyebabkan serat-serat pendek terpisah dari bahan dan pada saat pengayakan serat tersebut lolos pada saringan. Lolosnya serat pendek menyebabkan panjang serat rata-rata naik. Berdasarkan hasil pengamatan mikroskop (lihat Gambar 2) serat-serat pendek tersebut memiliki diameter yang lebih besar dibandingkan serat yang lebih panjang maka pada saat tersisihkan, akan membuat persentase rata-rata diameter serat menjadi lebih kecil. Hal ini didukung dengan naiknya nilai kelangsingan serat, yang menunjukkan bahwa serat ramping dengan diameter serat lebih kecil. Panjang serat minimal pada serpih bambu lebih kecil dibandingkan bambu dekortikasi. Serat yang terlalu pendek tidak diinginkan dalam produksi dissolving pulp karena mudah terdegradasi oleh alkali dan dalam pembuatan serat rayon viskosa akan menghasilkan serat dengan kekuatan mekanik rendah. Selain itu, serat pendek juga membuat penyaringan pada saat poses pembuatan viskosa menjadi sangat buruk (Hiro and Takahama, 1958). Rata-rata panjang serat bambu lebih panjang dari Eucalyptus spp. 0,568 mm-1,14 mm (Gominho et al., 2014; Carrillo et al., 2015; Neiva et al., 2015; Samistraro et al., 2015) dan setara dengan Pinus spp. 2,3 mm -3,6 mm (Ataç and Eroğlu, 2013; Gulsoy and Ozturk, 2015). Oleh karena itu, serat bambu tergolong serat panjang.

Bilangan runkel menggambarkan kemampuan bahan baku untuk dibuat pulp. Serat dengan

Tabel 3. Dimensi Serat dan Turunan Dimensi Serat Serpih Bambu dan Bambu Dekortikasi

\begin{tabular}{|c|c|c|c|}
\hline No & Parameter & $\begin{array}{l}\text { Serpih } \\
\text { bambu }\end{array}$ & $\begin{array}{c}\text { Bambu } \\
\text { dekortikasi }\end{array}$ \\
\hline 1 & $\begin{array}{l}\text { Panjang serat } \\
\text { maks. }(\mathrm{mm})\end{array}$ & 6,54 & 6,50 \\
\hline 2 & $\begin{array}{l}\text { Panjang serat } \\
\text { min. }(\mathrm{mm})\end{array}$ & 1,04 & 1,53 \\
\hline 3 & $\begin{array}{l}\text { Panjang serat } \\
\text { rata-rata }(\mathrm{mm})\end{array}$ & 2,46 & 3,31 \\
\hline 4 & $\begin{array}{l}\text { Diameter luar } \\
(\mu \mathrm{m})\end{array}$ & 22,35 & 20,04 \\
\hline 5 & $\begin{array}{l}\text { Diameter dalam } \\
(\mu \mathrm{m})\end{array}$ & 9,7 & 8,53 \\
\hline 6 & $\begin{array}{l}\text { Tebal dinding } \\
(\mu \mathrm{m})\end{array}$ & 6,33 & 5,76 \\
\hline 7 & Bilangan runkel & 1,3 & 1,35 \\
\hline 8 & Kelangsingan & 109,99 & 164,94 \\
\hline 9 & Kekakuan & 0,28 & 0,29 \\
\hline 10 & Kelenturan & 0,43 & 0,43 \\
\hline 11 & $\begin{array}{l}\text { Muhlstep ratio } \\
(\%)\end{array}$ & 81,17 & 81,90 \\
\hline
\end{tabular}


bilangan runkel kurang dari atau sama dengan satu berarti serat tersebut memiliki dinding serat tipis sehingga pelarut dan bahan kimia bisa menembus lebih mudah ke dalam serat dan mempermudah proses pemasakan (Sugesty, Kardiansyah and Hardiani, 2015). Bilangan runkel yang rendah juga akan menghasilkan pulp dengan kekuatan mekanik yang baik (Sharma et al., 2011). Bilangan runkel bambu duri lebih dari satu yang berarti bambu memiliki dinding serat yang tebal sehingga kemungkinan akan diperlukan bahan kimia yang lebih banyak pada proses pemasakan.

Selain dimensi serat, pengamatan morfologi serat juga dilakukan. Berdasarkan hasil foto serat, terlihat bentuk serat bambu dan sel parenkim. Seperti yang terlihat pada Gambar 2, sel parenkim pada bambu cukup banyak namun sel parenkim pada bambu dekortikasi lebih sedikit dibandingkan serpih bambu. Sel parenkim berbagai jenis bambu berkisar antara 17,1\%-26,9\% (Dhamodaran, Gnanaharan and Pillai, 2003). Sel parenkim memiliki efek negatif baik pada proses pembuatan maupun kualitas pulp dan kertas yang dihasilkan. Tingginya kandungan sel parenkim juga dapat mempengaruhi kualitas dissolving pulp yang dihasilkan. Zat abu pada bahan baku tidak tersebar merata, tetapi terutama terdeposit pada sel parenkim. Karena itu, proses pemasakan dan pemutihan harus mampu menyisihkan sel parenkim karena kandungan zat abu dapat menurunkan kualitas dissolving pulp yang dihasilkan (Wan Rosli et al., 2003; Cao et al., 2014).

\section{Komponen Kimia Serpih Bambu dan Bambu Dekortikasi}

Data hasil analisis komponen kimia tidak hanya digunakan untuk mengetahui kualitas bahan baku, namun juga digunakan untuk memprediksi kondisi proses pemasakan. Komponen kimia bambu terdiri atas selulosa, hemiselulosa, lignin, dan komponen minor yaitu ekstraktif dan abu. Kandungan komponen kimia bambu duri mirip dengan bahan baku yang biasa digunakan untuk pembuatan pulp dan kertas seperti Eucalyptus spp. dan Pinus spp., kecuali kandungan abu dan kelarutannya lebih tinggi. Bambu dekortikasi mengandung abu yang lebih rendah dibandingkan dengan serpih bambu. Hal ini dimungkinkan karena selama proses dekortikasi, zat mineral terlepas dari bahan karena perlakuan mekanik.

Kandungan selulosa alfa pada bambu duri lebih tinggi dari Eucalyptus spp. dan Pinus spp. Kandungan holoselulosa pada bambu setara dengan Eucalyptus spp., namun lebih tinggi dari Pinus spp. Kandungan selulosa alfa dan holoselulosa yang tinggi pada bahan baku akan menghasilkan rendemen pulp tinggi (Sugesty, Kardiansyah and Hardiani, 2015). Kandungan holoselulosa yang diperoleh lebih tinggi dari hasil penelitian Dransfield dan Widjaja (1995) yaitu sebesar $67,40 \%$.

Kelarutan dalam air dingin, air panas, dan $\mathrm{NaOH} 1 \%$ menggambarkan kandungan ekstraktif, hemiselulosa, dan selulosa terdegradasi. Kelarutan bambu yang tinggi menunjukkan
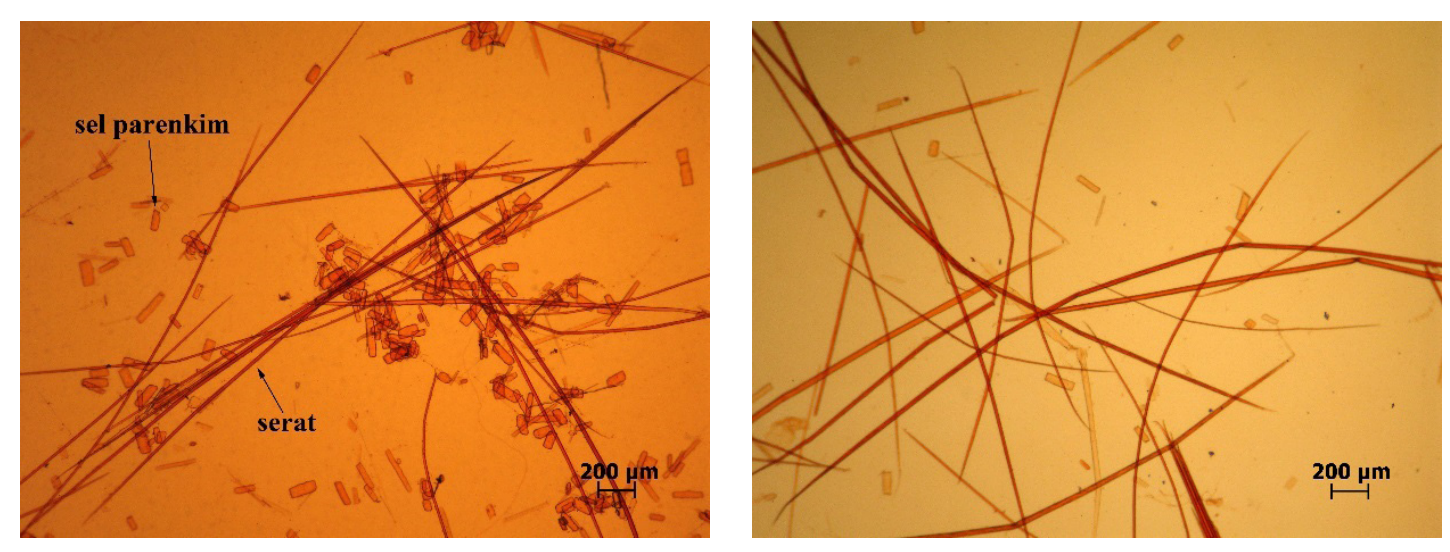

Gambar 2. Foto Serat Serpih Bambu dan Bambu Dekortikasi pada Perbesaran 40× 
Tabel 4. Komponen Kimia Serpih Bambu dan Bambu Dekortikasi

\begin{tabular}{|c|c|c|c|c|c|}
\hline No & Parameter & $\begin{array}{l}\text { Serpih } \\
\text { bambu }\end{array}$ & $\begin{array}{c}\text { Bambu } \\
\text { dekortikasi }\end{array}$ & Eucalyptus spp. ${ }^{1}$ & Pinus spp. ${ }^{2}$ \\
\hline 1 & Selulosa alfa $(\%)$ & 49,44 & 58,24 & $38,73-47,87$ & $41,8-52,98$ \\
\hline 2 & Holoselulosa (\%) & 74,45 & 83,47 & $55,40-76.68$ & $61,45-70,48$ \\
\hline 3 & Ekstraktif $(\%)$ & 4,80 & 3,10 & $2,11-3,7$ & $1,2-1,7$ \\
\hline 4 & Lignin klasson $(\%)$ & 23,20 & 24,32 & $15,9,10-32,53$ & $25,60-31,15$ \\
\hline 5 & Pentosan $(\%)$ & 20,90 & 13,91 & $12,15-25,51$ & $8,92-20,00$ \\
\hline 6 & Abu $(\%)$ & 4,52 & 2,59 & $0,14-4,2$ & $0,27-3,9$ \\
\hline 7 & Abu tak larut asam (\%) & 1,14 & 0,51 & - & - \\
\hline 8 & Kelarutan dalam air dingin $(\%)$ & 10,36 & 4,37 & $1,5-3,5$ & $1,3-1,64$ \\
\hline 9 & Kelarutan dalam air panas ( $\%)$ & 11,18 & 5,51 & $1,38-5,96$ & $1,41-7,37$ \\
\hline 10 & Kelarutan dalam $\mathrm{NaOH}$ 1\% (\%) & 28,70 & 25,26 & $17,1-23,4$ & $9,4-22,3$ \\
\hline
\end{tabular}

bahwa bambu tidak tahan terhadap penyimpanan karena selama penyimpanan, degradasi oleh bakteri, jamur, panas, cahaya dan lain-lain dapat terjadi. Kelarutan yang tinggi pada bambu terutama karena kandungan pati yang tinggi. Kelarutan bahan baku yang lebih tinggi akan menghasilkan rendemen pulp yang lebih rendah (Sharma et al., 2011).

Kandungan ekstraktif dan abu pada bambu cukup tinggi dibandingkan dengan kayu, baik kayudaun maupun kayujarum. Salah satu pembeda antara bahan baku nonkayu dan kayu adalah tingginya kandungan abu mineral pada nonkayu. Kandungan abu bambu duri merupakan salah satu yang tertinggi di antara spesies bambu lainnya. Kadar abu bambu sembilang $3,7 \%$, petung $2,13 \%$, mayan $1,66 \%$ (Sugesty, Kardiansyah and Hardiani, 2015), bambu hijau 1,5\% (Cao et al., 2014), apus 4,07\% (Mutia et al., 2014). Kandungan abu serpih bambu dan bambu dekortikasi sedikit lebih rendah dari hasil penelitian Dransfield dan Widjaja (1995) yaitu 4,80\%. Kandungan ekstraktif dan abu dari bahan baku dapat menyebabkan masalah seperti kesulitan dalam penanganan cairan lindi hitam, pengerakan, kerusakan peralatan, penyumbatan pipa, masalah pitch, dan terutama penurunan kualitas dissolving pulp. Oleh karena itu, ekstraktif dan abu harus disisihkan selama proses pemasakan.

\section{Karakteristik Pulp Belum Putih}

Tahapan pra-hidrolisis digunakan untuk menyisihkan hemiselulosa. Hemiselulosa harus disisihkan karena dapat mengganggu proses pembuatan serat rayon viskosa terutama pada proses spinning. Tingginya kandungan hemiselulosa pada dissolving pulp akan membuat benang serat rayon menjadi mudah putus pada proses spinning karena rantai hemiselulosa yang bercabang menyebabkan proses pembentukan serat rayon menjadi rapuh (Sixta, 2008).

Proses pemasakan serpih bambu dan bambu dekortikasi dilakukan pada kondisi yang sama dan hasil analisis rendemen dan bilangan Kappa pulp belum putih ditunjukkan pada Gambar 3 . Rendemen pulp belum putih bambu dekortikasi

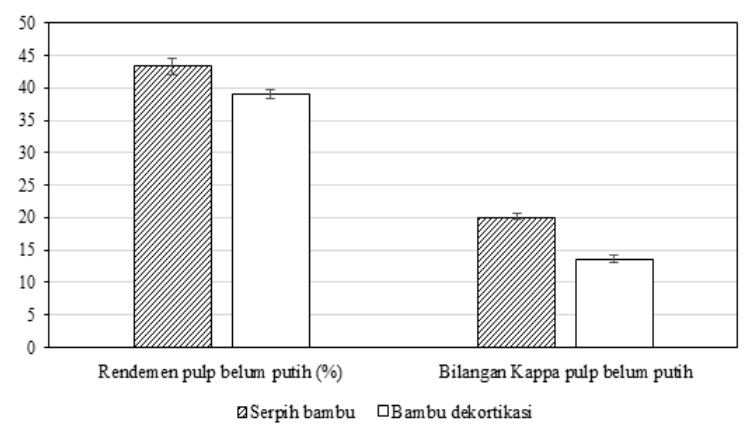

Gambar 3. Rendemen dan Bilangan Kappa Pulp Belum Putih dari Serpih Bambu dan Bambu Dekortikasi 
lebih rendah dibandingkan serpih bambu, hal itu dimungkinkan karena ukuran partikel bambu dekortikasi lebih kecil sehingga penetrasi cairan kimia pemasak lebih mudah (Gambar 1). Delignifikasi oleh cairan kimia pemasak akan lebih intensif sehingga menyebabkan rendemen dan bilangan Kappa lebih rendah. Pulp belum putih dari bambu dekortikasi memiliki bilangan Kappa $32,17 \%$ lebih rendah dibandingkan pulp dari serpih bambu.

\section{Rendemen dan Derajat Cerah Dissolving Pulp}

Pulp belum putih diputihkan menggunakan dua urutan pemutihan yang berbeda, yaitu $\mathrm{D}_{0} \mathrm{ED}_{1} \mathrm{D}_{2}$ dan $\mathrm{D}_{0} \mathrm{EpD}_{1} \mathrm{D}_{2}$. Rendemen dissolving pulp ditentukan berdasarkan berat kering oven bahan baku. Rendemen dissolving pulp berkisar antara 38,45 - 40,76\% (Gambar 4). Rendemen dissolving pulp dari bambu dekortikasi lebih rendah daripada serpih bambu. Dissolving pulp dari bahan baku yang sama namun urutan

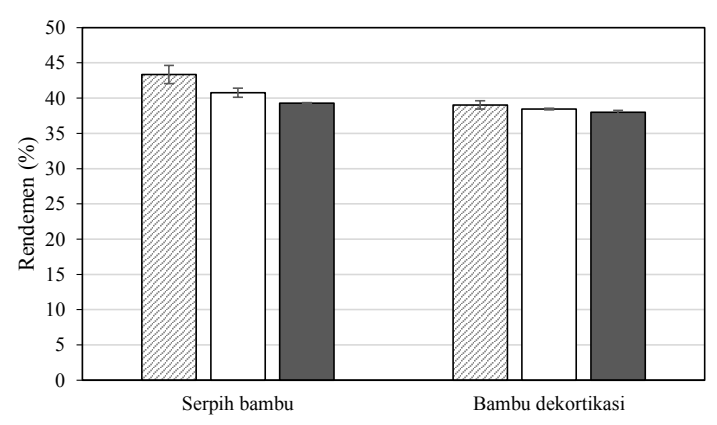

๑Pulp belum putih 口Dissolving pulp D0ED1D2 घDissolving pulp D0EpD1D2

Gambar 4. Rendemen Dissolving Pulp Bambu Duri dengan Tahapan Pemutihan $\mathrm{D}_{\mathrm{o}} \mathrm{ED}_{1} \mathrm{D}_{2}$ dan $\mathrm{D}_{\mathrm{o}} \mathrm{EpD}_{1} \mathrm{D}_{2}$

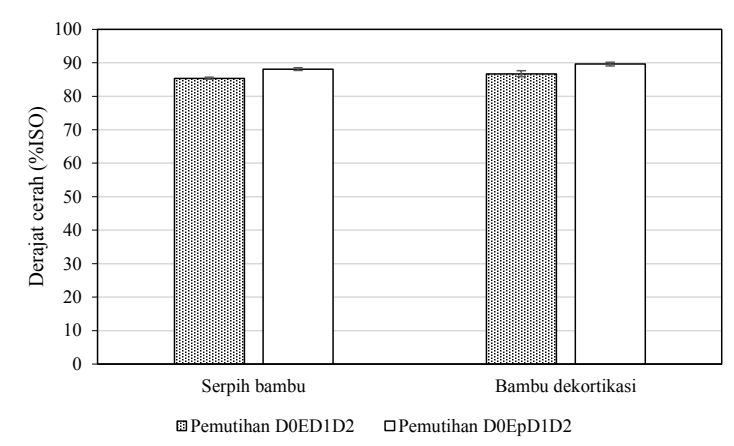

Gambar 5. Derajat Cerah Dissolving Pulp Bambu Duri dengan Tahapan Pemutihan $\mathrm{D}_{0} \mathrm{ED}_{1} \mathrm{D}_{2}$ dan $\mathrm{D}_{0} \mathrm{EpD}_{1} \mathrm{D}_{2}$ pemutihan yang berbeda menunjukkan rendemen dan derajat cerah yang berbeda. Urutan pemutihan $\mathrm{D}_{0} \mathrm{EpD}_{1} \mathrm{D}_{2}$ menghasilkan dissolving pulp dengan rendemen terendah yaitu $37,97 \%$ namun derajat cerah tertinggi yaitu $89,61 \%$. Penggunaan hidrogen peroksida dalam ekstraksi alkali pada tahap Ep mampu meningkatkan derajat cerah pulp namun menurunkan rendemen karena degradasi hidrogen peroksida yang tidak selektif yang menyerang lignin dan selulosa (Sixta, 2008).

\section{Karakteristik Dissolving Pulp}

Kandungan selulosa alfa keempat dissolving pulp di atas $94 \%$ dan memenuhi persyaratan menurut SNI 938:2017 - Pulp rayon. Dissolving pulp dengan kandungan selulosa alfa tinggi sangat sesuai untuk digunakan sebagai bahan baku pembuatan serat rayon viskosa (Sixta, 2008). Kelarutan dissolving pulp dalam natrium hidroksida $10 \%\left(\mathrm{~S}_{10}\right)$ dan $18 \%\left(\mathrm{~S}_{18}\right)$ menunjukkan kemurnian dissolving pulp. Kelarutan lebih rendah berarti kemurnian dissolving pulp yang lebih tinggi. Natrium hidroksida 10\% melarutkan hemiselulosa dan selulosa rantai pendek (polimer dengan berat molekul kurang dari $25000 \mathrm{~g} /$ mol) sedangkan natrium hidroksida $18 \%$ hanya melarutkan hemiselulosa (polimer dengan berat molekul kurang dari $8000 \mathrm{~g} / \mathrm{mol}$ ) (Strunk, 2012). Dissolving pulp dengan urutan pemutihan $\mathrm{D}_{\mathrm{o}} \mathrm{EpD}_{1} \mathrm{D}_{2}$ memiliki kandungan abu yang lebih tinggi dari pulp dissolving pulp dari $\mathrm{D}_{0} \mathrm{ED}_{1} \mathrm{D}_{2}$. Hal ini dimungkinkan karena natrium silikat yang digunakan untuk penyangga pada tahap Ep dapat terdeposit ke dalam serat.

Dalam ekstraksi alkali baik tanpa atau menggunakan peroksida, beberapa hemiselulosa larut dalam alkali yang menyebabkan kadar hemiselulosa menurun. Penurunan kandungan hemiselulosa dari pulp menyebabkan ekstraktif rentan terdeposit karena hemiselulosa bercabang bertindak sebagai penstabil dan penghalang sterik dari struktur bercabang hemiselulosa-alkalin. Penggunaan hidrogen peroksida dan natrium silikat pada tahap Ep menyebabkan ekstraktif menjadi lebih mudah flokulasi sehingga dissolving pulp yang dihasilkan oleh urutan pemutihan $\mathrm{D}_{\mathrm{o}} \mathrm{EpD}_{1} \mathrm{D}_{2}$ memiliki kandungan ekstraktif yang lebih tinggi (Varhimo et al., 2012).

Penggunaan hidrogen peroksida pada tahap ekstraksi alkali menurunkan viskositas dissolving pulp karena degradasi hidrogen peroksida berlangsung tidak selektif. Dissolving pulp dari 
Tabel 5. Hasil Analisis Dissolving Pulp Serpih Bambu dan Bambu Dekortikasi yang Diputihkan dengan Tahapan $\mathrm{D}_{\mathrm{o}} \mathrm{ED}_{1} \mathrm{D}_{2}$ dan $\mathrm{D}_{\mathrm{o}} \mathrm{EpD}_{1} \mathrm{D}_{2}$

\begin{tabular}{|c|c|c|c|c|c|c|c|}
\hline \multirow{2}{*}{ No } & \multirow{2}{*}{ Parameter } & \multirow{2}{*}{ Satuan } & \multicolumn{2}{|c|}{ Serpih bambu } & \multicolumn{2}{|c|}{ Bambu dekortikasi } & \multirow{2}{*}{$\begin{array}{c}\text { SNI 938:2017 } \\
\text { pulp rayon }\end{array}$} \\
\hline & & & $\mathrm{D}_{\mathrm{o}} \mathrm{ED}_{1} \mathrm{D}_{2}$ & $\mathrm{D}_{\mathrm{o}} \mathrm{EpD}_{1} \mathrm{D}_{2}$ & $\mathrm{D}_{\mathrm{o}} \mathrm{ED}_{1} \mathrm{D}_{2}$ & $\mathrm{D}_{\mathrm{o}} \mathrm{EpD}_{1} \mathrm{D}_{2}$ & \\
\hline 1 & Selulosa alfa & $\%$ & 94,88 & 95,93 & 98,11 & 98,67 & $\min .94$ \\
\hline 2 & $\mathrm{~S}_{10}$ & $\%$ & 6,64 & 6,33 & 6,25 & 6,22 & maks. 7,9 \\
\hline 3 & $\mathrm{~S}_{18}$ & $\%$ & 4,07 & 3,57 & 3,58 & 3,59 & maks. 4,9 \\
\hline 4 & Ekstraktif DCM & $\%$ & $\mathrm{td}$ & 0,11 & $\mathrm{td}$ & 0,17 & maks 0,2 \\
\hline 5 & $\mathrm{Abu}$ & $\%$ & 0,12 & 0,22 & 0,10 & 0,14 & maks. 0,15 \\
\hline 6 & $\begin{array}{l}\text { Viskositas pada } \\
\text { CED }\end{array}$ & $\begin{array}{l}\mathrm{mPa} . \mathrm{s} \\
\text { atau cP }\end{array}$ & 25,75 & 19,19 & 18,46 & 16,43 & $\min .6,2$ \\
\hline 7 & Viskositas intrinsik & $\mathrm{mL} / \mathrm{g}$ & 721 & 619 & 731 & 553 & $\min .400$ \\
\hline 8 & Derajat cerah & $\%$ ISO & 85,38 & 88,10 & 86,72 & 89,61 & $\min .88$ \\
\hline
\end{tabular}

bambu dekortikasi dengan urutan pemutihan $\mathrm{D}_{\mathrm{o}} \mathrm{EpD}_{1} \mathrm{D}_{2}$ memiliki viskositas paling rendah. Dalam pembuatan serat rayon viskosa, viskositas intrinsik yang diinginkan dari dissolving pulp untuk pembuatan rayon viskosa berada pada kisaran 400 $\mathrm{mL} / \mathrm{g}$ sampai $600 \mathrm{~mL} / \mathrm{g}$, dan perlu diturunkan kembali menjadi $200 \mathrm{~mL} / \mathrm{g}$ sampai $250 \mathrm{~mL} / \mathrm{g}$ pada proses pemeraman (aging) (Chen et al., 2016). Viskositas yang terlalu rendah menyebabkan masalah pada filtrasi viskosa dan juga dapat menyebabkan penurunan kekuatan fisik serat rayon viskosa (Miao et al., 2014) sedangkan viskositas yang terlalu tinggi menyebabkan beberapa kesulitan pada tahap pemeraman karena memakan waktu lebih lama untuk mendapatkan viskositas diinginkan atau dengan menambahkan katalis seperti $\mathrm{MnSO}_{4}$ untuk membantu degradasi selulosa. Viskositas dissolving pulp yang terlalu tinggi membuat viskosa terlalu kental sehingga secara mekanis sulit untuk diolah (Javed et al., 2014). Meskipun dissolving pulp dari bambu dekortikasi dengan urutan pemutihan $\mathrm{D}_{\mathrm{o}} E p \mathrm{D}_{1} \mathrm{D}_{2}$ memiliki viskositas intrinsik terendah, namun nilainya tetap dapat diterima untuk pembuatan rayon. Dissolving pulp tersebut memiliki kelebihan karena derajat cerahnya tinggi sehingga bisa menghasilkan serat rayon yang putih dan berkualitas.

\section{Kesimpulan}

Bambu duri (Bambusa blumeana) memiliki potensi yang baik untuk digunakan sebagai bahan baku pembuatan dissolving pulp serat panjang. Berdasarkan hasil analisis dimensi serat, panjang serat rata-rata bambu duri adalah 2,46 $\mathrm{mm}$ sehingga tergolong serat panjang. Komponen kimia bambu duri sebanding dengan Eucalyptus spp. dan Pinus spp. kecuali kadar abu dan kelarutan $\mathrm{NaOH} 1 \%$ yang lebih tinggi. Persiapan bahan baku dan tahapan pemutihan pulp menentukan kualitas dissolving pulp yang dihasilkan. Dissolving pulp dari bambu dekortikasi memiliki rendemen yang lebih rendah dibandingkan serpih bambu. Dissolving pulp dengan tahapan pemutihan $\mathrm{D}_{0} \mathrm{EpD}_{1} \mathrm{D}_{2}$ memiliki derajat cerah dan kadar abu yang lebih tinggi dibandingkan tahapan pemutihan $\mathrm{D}_{0} \mathrm{ED}_{1} \mathrm{D}_{2}$, namun kandungan selulosa alfa dan viskositas lebih rendah. Bambu dekortikasi dengan tahapan pemutihan $\mathrm{D}_{\mathrm{o}} \mathrm{EpD}_{1} \mathrm{D}_{2}$ menghasilkan dissolving pulp dengan kualitas yang paling unggul dengan kandungan selulosa alfa dan derajat cerah tertinggi masing-masing $98,67 \%$ dan $89,61 \%$ ISO.

\section{Ucapan Terima Kasih}

Penelitian ini dibiayai oleh DIPA Balai Besar Pulp dan Kertas tahun anggaran 2016. Penulis mengucapkan terima kasih kepada Pusat Penelitian dan Pengembangan Rehabilitasi dan Konservasi Hutan, para peneliti dan teknisi litkayasa Balai Besar Pulp dan Kertas yang membantu terlaksananya penelitian ini. 


\section{Daftar Pustaka}

Antes, R. and Joutsimo, O. P. (2015) 'Effect of modified cooking on bleachability of Eucalyptus globulus and Eucalyptus nitens', BioResources, 10(1), pp. 597-612.

Ariyanti, R. (2018) Kemenperin Berharap pada Industri Pulp Larut dan Rayon untuk Gantikan Impor. Available at: http://industri.bisnis.com/ read/20180228/257/743314/ kemenperinberharap-pada-industri-pulp-larut-dan-rayonuntuk-gantikan-impor (Accessed: 5 July 2018).

Ataç, Y. and Eroğlu, H. (2013) 'The effects of heartwood and sapwood on kraft pulp properties of Pinus nigra J.F.Arnold and Abies bornmuelleriana Mattf', Turkish Journal of Agriculture and Forestry, 37(2), pp. 243-248. doi: 10.3906/tar-1205-20.

Batalha, L. A. R. et al. (2012) 'Dissolving pulp production from bamboo', BioResources, 7(1), pp. 640-651.

Biermann, C. J. (1996) Handbook of Pulping and Papermaking. 2nd edn. California: Elsevier Inc. doi: 10.1016/B978-0120973620/50008-X.

Cao, S. et al. (2014) 'Morphological and chemical characterization of green bamboo (Dendrocalamopsis oldhami (Munro) Keng f.) for dissolving pulp production', BioResources, 9(3), pp. 4528-4539. Available at: http://ojs. cnr.ncsu.edu/index.php/ BioRes/article/view/ BioRes_09_3_4528_Cao_Green_Bamboo_ Pulp_Production.

Carrillo, I. et al. (2015) 'Variations in wood anatomy and fiber biometry of Eucalyptus globulus genotypes with different wood density', Wood Research, 60(1), pp. 1-10.

Castillo, R. del P. et al. (2015) 'Fourier transform infrared imaging and microscopy studies of Pinus radiata pulps regarding the simultaneous saccharification and fermentation process', Analytica Chimica Acta. Elsevier B.V., 866(January), pp. 10-20. doi: 10.1016/j. aca.2015.01.032.

Chen, C. et al. (2016) 'Cellulose (dissolving pulp) manufacturing processes and properties: A mini-review', BioResources, 11(2), pp. 5553-5564. doi: 10.15376/biores.11.2.Chen.

Cotana, F. et al. (2014) 'Production of bioethanol in a second generation prototype from pine wood chips', Energy Procedia. Elsevier B.V., 45, pp. 42-51. doi: 10.1016/j.egypro.2014.01.006.
Dhamodaran, T. K., Gnanaharan, R. and Pillai, K. S. (2003) Bamboo for Pulp and Paper - A State of the Art Review, Working paper. Kerala. Available at: http://www.inbar.int/ sites/default/files/resources/inbar_working paper_no46.pdf.

Dransfield, S. and Widjaja, E. A. (1995) 'Bamboos', Plant Resource of South-East Asia, (7), p. 185.

Duan, C. et al. (2015) 'Comparison of acid sulfite (AS)- and prehydrolysis kraft (PHK)based dissolving pulps', Cellulose. Springer Netherlands, 22(6), pp. 4017-4026. doi: 10.1007/s10570-015-0781-1.

Gallina, G. et al. (2016) 'Optimal conditions for hemicelluloses extraction from Eucalyptus globulus wood: Hydrothermal treatment in a semi-continuous reactor', Fuel Processing Technology. Elsevier B.V., 148, pp. 350-360. doi: 10.1016/j.fuproc.2016.03.018.

Gominho, J. et al. (2014) 'Eucalyptus globulus stumpwood as a raw material for pulping', BioResources, 9(3), pp. 4038-4049. doi: 10.15376/biores.9.3.4038-4049.

Gulsoy, S. K. and Ozturk, F. (2015) 'Kraft pulping properties of European black pine cone', Maderas. Ciencia y tecnología, 17(4), pp. 875-882. doi: 10.4067/S0718221X2015005000076.

Gulsoy, S. K. and Tufek, S. (2013) 'Effect of chip mixing ratio of Pinus pinaster and Populus tremula on Kraft pulp and paper properties', Industrial \& Engineering Chemistry Research, 52(6), pp. 2304-2308. doi: 10.1021/ie302709e.

Herrera, R. et al. (2014) 'Characterization of hydrothermally treated wood in relation to changes on its chemical composition and physical properties', Journal of Analytical and Applied Pyrolysis, 107, pp. 256-266. doi: 10.1016/j.jaap.2014.03.010.

Hiro, M. and Takahama, M. (1958) 'Studies on manufacturing dissolving pulp from bagasse', Bulletin of the Institute for Chemical Research, 36(5), pp. 172-180.

Hou, Y. et al. (2016) 'Application of alkaline ionic liquids in the pretreatment process of eucalyptus kraft pulping', Bio Resources, 11(4), pp. 9036-9046.

Javed, M. U. et al. (2014) Viscose Fiber Strength and Degree of Polymerization. Available at: https://www.researchgate.net/ publication/268629417_Viscose_Fiber_ Strength_and_Degree_of_Polymerization. 
Kojima, Y. et al. (2014) 'Photoyellowing of chemically modified chemithermomechanical pulps (CTMP) from Eucalyptus globulus under various atmospheres', Holzforschung, 68(2), pp. 143-149. doi: 10.1515/hf-2013-0086.

Luo, X. et al. (2014) 'Comparison of hot-water extraction and steam treatment for production of high purity-grade dissolving pulp from green bamboo', Cellulose, 21(3), pp. 1445-1457. doi: 10.1007/s10570-014-0234-2.

Ma, X. et al. (2011) 'Preparation of bamboo dissolving pulp for textile production. Part 1 . Study on prehydrolysis of green bamboo for producing dissolving pulp', BioResources, 6(2), pp. 1428-1439.

Maya, C. and Narasimhamurthy (2015) 'A study on chemical and anatomical properties of cultivated bamboo Thyrsostachys siamensis gamble.', Journal of Global Biosciences, 4(1), pp. 1313-1319.

Miao, Q. et al. (2014) 'A process for enhancing the accessibility and reactivity of hardwood kraft-based dissolving pulp for viscose rayon production by cellulase treatment', Bioresource Technology, 154, pp. 109-113. doi: 10.1016/j. biortech.2013.12.040.

Mutia, T. et al. (2014) 'Potensi serat dan pulp bambu untuk komposit peredam suara', Jurnal selulosa, 4(1), pp. 25-36.

Neiva, D. et al. (2015) 'Chemical composition and kraft pulping potential of 12 eucalypt species', Industrial Crops and Products, 66, pp. 30-30. doi: 10.1016/j.indcrop.2014.12.016.

Pinto, E. M. et al. (2016) 'Thermal degradation and charring rate of and wood species', The Open Construction and Building Technology Journal, 10(Suppl 3: M8), pp. 450-456. doi: $10.2174 / 1874836801610010450$.

Poletto, M. (2016) 'Effect of extractive content on the thermal stability of two wood species from Brazil', Maderas. Ciencia y tecnología, 18(3), pp. 435-442. doi: 10.4067/S0718$221 \times 2016005000039$.

Reyes, P. et al. (2016) 'Evaluation of combined dilute acid-kraft and steam explosion-kraft processes as pretreatment for enzymatic hydrolysis of Pinus radiata wood chips', BioResources, 11(1), pp. 612-625. doi: 10.15376/biores.11.1.612-625.

Samistraro, G. et al. (2015) 'Chemical, anatomical, and technology aspects of Eucalyptus benthamii and Eucalyptus dunii for use in an integrated pulp and paper mill', Tappi Journal, 14(2), pp. 73-81.
Sharma, A. K. et al. (2011) 'Anatomical, morphological, and chemical characterization of Bambusa tulda, Dendrocalamus hamiltonii, Bambusa balcooa, Melocana baccifera, Bambusa arundinacea and Eucalyptus tereticornis', BioResources, 6(4), pp. 5062-5073.

Sixta, H. (2008) Handbook of Pulp, Handbook of Pulp. Weinheim: Wiley-VCH. doi: 10.1002/9783527619887.

Strunk, P. (2012) Characterization of Cellulose Pulps and The Influence of Their Properties on The Process and Production of Viscose and Cellulose Ethers. Umeå Universitet.

Sugesty, S., Kardiansyah, T. and Hardiani, H. (2015) 'Bamboo as raw materials for dissolving pulp with environmental friendly technology for rayon fiber', Procedia Chemistry. Elsevier Ltd., 17, pp. 194-199. doi: 10.1016/j. proche.2015.12.122.

Tian, C. et al. (2013) 'Improvement in the Fock test for determining the reactivity of dissolving pulp', Tappi Journal, 12(11), pp. 21-26.

Truong, A. H. and Le, T. M. A. (2014) Overview of Bamboo Biomass for Energy Production. University of Sciences and Technologies of Hanoi. Available at: https://halshs.archivesouvertes.fr/halshs-01100209 (Accessed: 1 May 2017).

Valenzuela, R. et al. (2016) 'Fiber modifications by organosolv catalyzed with $\mathrm{H}_{2} \mathrm{SO}_{4}$ improves the SSF of Pinus radiata', Industrial Crops and Products. Elsevier B.V., 86, pp. 79-86. doi: 10.1016/j.indcrop.2016.03.037.

Varhimo, P. et al. (2012) 'Brightness reduction of mechanical pulp in the wet end of a paper machine: Method development and validation', Nordic Pulp \& Paper Research Journal, 27(3), pp. 542-549. doi: 10.3183/NPPRJ-2012-2702-p542-549.

Wan Rosli, W. D. et al. (2003) 'Optimisation of soda pulping variables for preparation of dissolving pulps from oil palm fibre', Holzforschung, 57(1), pp. 106-113. doi: 10.1515/HF.2003.017.

Xiang, H. L. and He, J. (2013) 'Mechanisms and defiberation point of Pinus kesiya diethanolamine pulping', Advanced Material Research, 807-809, pp. 505-508. doi: 10.4028/ www.scientific.net/AMM.291-294.347.

Zhou, C. et al. (2015) 'Prediction of mixed hardwood lignin and carbohydrate content using ATR-FTIR and FT-NIR', Carbohydrate Polymers. Elsevier Ltd., 121(May), pp. 336341. doi: 10.1016/j.carbpol.2014.11.062. 
Jurnal Selulosa, Vol. 8, No. 1, Juni 2018: 21 - 32 